\title{
Shooting Felons: Law, Practice, Official Culture, and Perceptions of Morality ${ }^{1}$
}

\author{
A.W. BRIAN SIMPSON*
}

Until a change in the law in 1967 felons might be shot in order to prevent escape from lawful custody; their death counted as justifiable homicide. Shooting escaping felons came to be particularly associated with Dartmoor Prison, where outside working parties were accompanied by armed guards until the 1950s. But many years before this, administrative action had been directed towards ensuring that fatal shootings should not occur; the last such incident took place in the nineteenth century. This article traces the history of the relationship between formal law and administrative practice.

The common law divided criminal offences into treasons, felonies, and misdemeanors. One consequence of the distinction between felonies and misdemeanors was, for many years, of particular significance to prisoners serving sentences of penal servitude in convict prisons. Felons were liable to be shot if they tried to escape, but misdemeanants were not regarded as legitimate game. The distinction between felony and misdemeanor was retained in the law until 1967. In that year the Criminal Law Act, by s. 1(1), abolished all distinctions between felonies and misdemeanors, and by s. 1(2) provided that in future the law relating to felonies should be that which then applied to misdemeanors. ${ }^{2}$ This Act, by s. 3, made explicit provision for the use of lethal force, laying down a test of reasonable necessity. ${ }^{3}$

The shooting of felons was particularly associated with Dartmoor Prison. It is the most isolated of all English prisons, and in the past its isolation was

* University of Michigan Law School, Hutchins Hall, Ann Arbor, MI 481091215, United States of America

bsimpson@umich.edu

1 This article is based primarily on material in the classes HO 45, 144. and 326 and PCOM 7, 8, and 9 in the National Archives.

2 See Criminal Law Act, Part I, ss. 1-12.

3 See the Northern Irish case of Regina v. MacNaughton [1975] NI 303. 
even more striking. ${ }^{4}$ Originally known as the Depot at Dartmoor, it was built to house prisoners from the Napoleonic wars. ${ }^{5}$ Its bizarre location provided enhanced security. It opened in 1809. It was used to house American prisoners, and its early history was marked by violence, for on 6 April 1815, prompted by fear of a mutiny, the authorities opened fire on the prisoners. Seven were killed at once, and two died later after amputations; some fifty other prisoners were wounded. At the coroner's inquest verdicts of justifiable homicide were returned, but the government accepted responsibility, and paid pensions to the wounded and to their dependants. ${ }^{6}$ By February 1816 the prisoners of war had gone and the buildings were abandoned. When transporting convicts to the colonies began to run into difficulties schemes were developed for long-term imprisonment in penitentiaries. Prisoners were at this period mainly held in the hulks. In 1836 a scheme to use Dartmoor for juvenile criminals, in substitution for the Albany Barracks at Parkhurst on the Isle of Wight, ${ }^{7}$ was mooted, but nothing came of this. In 1837 Colonel Joshua Jebb, ${ }^{8}$ Surveyor General of Prisons, proposed that it should be used for longterm adult prisoners, who could be profitably employed locally on land reclamation and in the granite quarries. So in 1850 , under the newly formed Directors of Convict Prisons, Dartmoor became a convict prison. ${ }^{9}$ There were civilian warders, and a quite distinct armed military guard. Its principal function was to guard the prisoners when working outside the prison. In April 1854 the military guards were replaced by what were known as civil guards. These were, at first at least, recruited from elderly army pensioners. ${ }^{10}$

After 1868, and possibly before, their muskets were replaced by rifled Snider Enfield rifles or carbines. These breach loading weapons had been adopted for military use in 1866 . So it was that from the very beginning Dartmoor was associated with outside working parties controlled by armed guards.

4 A steam railway to Princetown was opened in 1880; it has since been closed.

5 See B.H. Thomson, The Story of Dartmoor (1907), The Criminal (1925), and The Scene Changes (1937).

6 See C. Andrews, The Prisoner's memoirs, or Dartmoor Prison ... Also a Particular Detail of All Occurrences Relating to that Horrid Massacre on the Evening of the 6th April 1815 (1852), B. Waterhouse, A Journal of a Young Man of Massachusetts etc. (1911).

7 These became Parkhurst Convict Prison in 1839.

8 1793-1863. He was an engineer officer who had designed the model cellular Pentonville Prison, opened in 1842.

9 The Directors were initially responsible for two prisons used to provide separate accommodation for each prisoner, Millbank and Pentonville, cells devoted to this function in eight local prisons, for one prison for juveniles, Parkhurst, for four hulks containing prisoners whom it was hoped to transport, and for two invalid depots, one being a hulk and the other a barracks at Shorncliffe. In addition, they were responsible for two public works prisons, Dartmoor and Portland.

10 Information from the 1901 census of Lydford Parish indicates that this was no longer the case, and according to F. Wilkinson. 217, the practice or recruiting pensioners had ended in 1857. 
Movies I watched as a child imprinted on me a clear picture of life in an English convict prison, and the paradigm was always Dartmoor. The prisoners, unshaven and with cropped hair, ${ }^{11}$ and attired in grotesque illfitting garments covered with broad arrows, toiled away breaking stone, whilst around them stood the armed guards. Mist swirled about the place, and occasionally a convict would make a run for it; he either rapidly repented of this, or was shot. Very, very, occasionally and always when there was thick fog, one made it onto the moor, the bell was rung, and we were in the world of The Hound of the Baskervilles ${ }^{12}$ and of the felon Selden, brother-in-law to the Baskerville Hall butler, Barrymore, who was pursued through an unfortunate error by the hound. He ended up dead and spreadeagled, and lucky, I suppose, not have perished more slowly in the Grimpen Mire. ${ }^{13}$ I was indeed reminded of all this when, in 1950, I attended a battle school on Dartmoor, in which we used live ammunition in our training. The cadet on the machine gun, one Evelyn Morgan, had lost the relevant pane of his spectacles and was, one way and another, thereby rendered as blind as a bat. Fearful of accusations of incompetence if he reported this to the instructor, he said nothing. ${ }^{14}$ In misty conditions, he sprayed us with machine gun fire. We responded by burying ourselves as deep as we could in the local equivalent of the Grimpen Mire. We escaped uninjured.

My vision of Dartmoor was not fanciful. In 1946 Dr. J.C.W. Methuen, one of the Prison Commissioners, wrote a report on a Borstal Institution then established in the prison. He explained that the Home Office was ashamed of the place, mainly because of the antediluvian nature of the ill-maintained buildings, on which, in anticipation of closure, little money had been spent. He added that:

11 Close cropping of hair ended in 1922, and from the following year prisoners were allowed to shave regularly. See Report of the Commissioners of Prisons and Directors of Convict Prisons for 1934 ((1935); Cmd. 5153) which gives an account of changes in the previous twenty five years.

12 First published as a serial in the Strand Magazine in 1901-2, and then in book form in 1902.

13 When Conan Doyle was working on the story in 1901 he visited Dartmoor, staying for a while in the Duchy Hotel in Princetown, where it is said he was visited by the Governor, the Doctor, and the Chaplain. It is said that the name Selden was that of an officious prison warder. See M. Booth, The Doctor, the Detective and Arthur Conan Doyle. A Biography of Arthur Conan Doyle (1997); C. Higham, The Adventures of Conan Doyle. The Life of the Creator of Sherlock Holmes (1976) at 168 and ff.; D. Staghower, Teller of Tales. A Life of Arthur Conan Doyle (1999) ch. 17. The census returns of 1881,1891 and 1901 do not record an prison officer named Selden as living in the area.

14 If you failed to perform satisfactorily at the battle school you were 'RTU-ed', returned to unit, thereby losing the chance to become an officer and not wear scratchy shirts. When I was at the Eaton Hall Officer Cadet Training Unit. there was a young lady who frequented a dance hall in Chester, all of whose officer cadet boyfriends had been returned to unit. She was known as RTU Sheila. 
Since I have known anything of the prisons of this country I have always heard on all sides that the most dreadful thing that could happen to any prisoner was to send him to Dartmoor. There hangs over the place a mist of tradition that makes all uninstructed people to believe that to go to Dartmoor is only one degree better than being condemned to death. ${ }^{15}$

\section{Wilfred Macartney wrote in 1936:}

When a wretched prison like Dartmoor is added to the harsh English prison discipline, it can be imagined with what horror the convict regards the prospect of doing his time on the moor. Men will maim themselves not to go there; they will attempt suicide to be transferred to Parkhurst. ${ }^{16}$

This fearsome reputation was reinforced by the practice of shooting its denizens.

In January 1952 George Benson, Chairman of the Howard League for Penal Reform and a Member of Parliament, visited the prison as a member of the Advisory Council on the Treatment of Offenders, established in 1944 . He thought the prison should, under a new name, perhaps Princetown, be developed into a secure long-term training prison. But its reputation had to be changed:

When Dartmoor was first founded in 1808 for the reception of French prisoners of war it rapidly and with justification achieved an evil reputation which it has never succeeded in shaking off. For a century it has been associated in the public mind with desperate criminality, and to all appearances in the official mind also. The traditional toughness of the prison and the prisoners is symbolised by 'the warder with the rifle'. I believe the carrying of rifles is extremely unfortunate psychologically and I doubt if the atmosphere of Dartmoor will ever become normal whilst it continues. ${ }^{17}$

Conan Doyle made use of this in The Hound of the Baskervilles. For when Dr. Mortimer and Dr. Watson arrive by train at the station on the moor:

'Halloa!' cried Dr. Mortimer, 'what is this?'

A steep curve of heath-clad land, an outlying spur of the moor, lay in front of us. On the summit, hard and clear like an equestrian statue upon its pedestal, was a mounted soldier, dark and stern, his rifle poised ready upon his forearm.

It will be recalled that Dr. Watson was not prepared to shoot Selden, an unarmed man, when he was running away. But if he had, the death would have ranked as justifiable homicide.

At the time of Benson's report the management of the prison had been considerably liberalized; thus the last occasion on which a convict had been flogged was $1942 .{ }^{18}$ From time to time there were escapes, but for very

15 PCOM 9/1970.

16 W. Macartney, Walls Have Mouths. A Record of Ten Years Penal Servitude (1936) at 238. He himself did not serve time in Dartmoor.

17 HO 326/66. See, also, A.J. Rhodes, Dartmoor Prison. A Record of 126 Years of Prisoner of War and Convict Life, 1806-1932 (1933) at 4.

18 The first year in which no prisoner had been corporally punished was 1935 . The figures for some earlier years were 1926 (2), 1927 (4), 1928 (3), 1929 (2), 1930 (4), 1931 (2), 1932 (6). 
many years only two convicts had succeeded in getting off the moor before recapture. Benson went on:

The carrying of rifles is of sufficient importance to warrant careful consideration as to whether it is really necessary. It is true that while the moor makes successful escapes extremely difficult it may be an invitation to attempts by prisoners working in the open. But in law only a felon may be shot in attempting to escape; misdemeanants may not. The distinction between misdemeanants and felons is largely a mediaeval survival, and certainly has no practical value for purposes of prison classification. As the Dartmoor population is a mixture of misdemeanants and felons it is largely a matter of obsolete legal classification whether a prisoner works under an armed guard or not.

What was the rationale for the legal right to shoot escaping felons? Originally the commission of any felony subjected the felon to liability to capital punishment. There was a certain logic in the claim that against a felon deadly force could be used in order to prevent escape from justice; felons were liable to be killed after conviction, and should not be allowed to cheat the gallows. They were living on borrowed time. Various passages could be cited from the old writers on criminal law, in particular Hale ${ }^{19}$ and Hawkins; ${ }^{20}$ if a felon was escaping and could not otherwise be taken, killing him did not rank as a felony, but would be justifiable homicide. But fleeing misdemeanants could not be so killed. ${ }^{21}$ When this doctrine first appears, long-term imprisonment by way of punishment for felons had not yet been invented, and the passage in Hale is addressed to felons evading arrest. Hale's doctrine is based upon two ideas. One is that a killing may be justifiable for the advancement of public justice, as when a person is executed, and the other is that officials engaged in the advancement of public justice are under the special protection of the law. He wrote in relation to the power and duty of a constable to arrest a felon:

If the felon resist and cannot be taken, whether it be after the arrest or before, the killing of the felon, who cannot otherwise be taken, is no felony. But the reason for all this is, because he is ex officio a conservator of the peace, and is not only permitted but by law enjoined to take a felon, and if he omits his duty herein, he is indictable and subject to a fine or imprisonment. ${ }^{22}$

In Hawkin's Pleas of the Crown the doctrine turns up in a more extended form. And an indicted felon who fled might similarly be slain even if

19 M. Hale, Pleas of the Crown, vol. I (1736) 481, 490, 494; vol. II, 91. Hale at I.481 says that 'if a felon flies, and he cannot otherwise be taken, if he is killed it is no felony, and in that case the officer so killing forfeits nothing'.

20 id., vol. I, 28, 11-13.

21 The doctrine is not to be found in editions of Archbold's Criminal Pleading, Evidence and Procedure, which came to be the treatise most relied upon by practitioners in the administration of the criminal law. A version does appear in Russell.

22 Hale, op. cit., n. 19, II.89. 
innocent of the felony, since he must submit to trial. ${ }^{23}$ Foster, writing in the eighteenth century, stated:

But where a felony is committed, and the felon flieth from justice, or a dangerous wound is given, it is the duty of every man to use his best endeavours for preventing an escape; and if in the pursuit the party flying is killed, where he cannot be otherwise overtaken, this will be deemed justifiable homicide. [emphasis in original]

As for the rationale he explains, 'These rules are founded on public utility, ne maleficia remanet impunita.' 24 Doctrines whose function it was to ensure that felons were brought to trial evolved in a world in which modern policing did not exist.

By the mid-nineteenth century, most felonies no longer carried a liability to capital punishment; felons were normally sentenced to periods of penal servitude. $^{25}$ Apparently firearms, as well no doubt as other weapons, had long been used to assist in containing prisoners in the hulks. ${ }^{26}$ But little seems to be discoverable about their use. As a Home Office memorandum of 1897 explains:

While it is clear that the use of Fire Arms in the safeguarding of Convicts prevailed before 1851, and probably from the commencement of the Hulk system, it appears, from the papers still available, that it was not until that year that any steps were taken to provide regulation for their employment in repressing outbreaks or escapes. ${ }^{27}$

Firearms might be held in prisons for various reasons: to provide selfdefence for warders, to quell mutinies, as well as to prevent escapes. Stocks of weapons, some very antique, were indeed commonplace in all prisons, including local prisons, until $1926 .^{28}$

In 1851 Captain Whitby, the governor of Portland Prison, opened in 1848, asked for a supply of weapons similar to those held at this time in Pentonville, Parkhurst, and Dartmoor; those he had in Portland were, in his view, unsuitable. Probably he wanted Snider Enfield rifles rather than muzzle-loading muskets. By now in some prisons the practice had developed

23 W. Hawkins, Pleas of the Crown (1762) I 489.

24 M. Foster, Crown Law (Report of Some Proceedings ... to which are Added Discourses upon a Few Branches of the Crown Law) (2nd edn., 1791) Discourse II, ch. 2.

25 Penal servitude dates from 1853.

26 See PCOM 9/98, letter of 26 March 1952 from Joshua Jebb, noting the escape of one convict from the hulk York at Gosport, and two from the hulk Defence at Woolwich. F. Wilkinson (Those Entitled to Bear Arms (2002) at 221) notes that Henry Mayhew, in Criminal Prisons in London (1862), mentions the use of armed guards in the hulks.

27 HO 45/9743/A55944. Probably by W.B. Penny. What follows relies on this memorandum.

28 See PCOM 7/194; some weapons of historical interests were retained as curios. This change did not apply to the convict prisons Dartmoor, Parkhurst, and Portland. 
of employing convicts on public works outside the prison walls. The reasons were partly economic; convicts could be made to pay for the costs of their incarceration. In part they were moral: hard work could lead to redemption. The idea of employing convicts on public works was enthusiastically supported in a report produced in 1846 by Joshua Jebb. ${ }^{29}$ The implementation of Jebb's ideas began in 1850 with the establishment of the Board of Directors of Convict Prisons, with Jebb as its first chairman. Public works were set in hand at Portland ${ }^{30}$ and Chatham, ${ }^{31}$ where new naval dockyards were under construction, and Dartmoor, where the prisoners worked in stone quarries, on land reclamation, and on the prison farm. ${ }^{32}$ In the early days of this system some prisoners were also sent to work in Gibraltar and Bermuda.

For members of outside work parties, opportunities for escape certainly did exist. Convicts could of course be shackled together, but this would interfere with their work. ${ }^{33}$ The prisoners had to use tools, which could easily be used as weapons. A possible solution to the problems created by outside working parties was to employ armed guards, and threaten to shoot any convict who attempted to flee. This was the background to Captain Whitby's wish to have up-to-date weapons to assist in the management of his public works prison.

The Directors of Convict Prisons recommended that firearms be provided, but should be loaded only with buckshot, rather than with a single ball, as being less deadly. For the officials were at all times conscious of the fact that killing escaping convicts simply to prevent their escape was not easy to justify, rationally or morally; what they really wanted was the advantages of a deterrent without the embarrassing reality of dead felons. At some point the use of buckshot became the norm, each armed guard carrying five appropriate cartridges. ${ }^{34}$ An incidental advantage of using buckshot was that it spread, making a hit rather more likely, if less lethal. The directors also asked for definite instructions which would protect either civil or military guards in the use of firearms both in cases of mutiny, ${ }^{35}$ and in cases

29 See L. Radzinowich and R.G. Hood, A History of English Criminal Law vol. 5 (1986) at 490 ff., based on Report on Convict Discipline by Major Jebb R.E.

30 Opened 1848. It ceased to be a public works prison in 1914.

31 Opened 1856.

32 The other convict prisons by 1881 were Borstal, Brixton, Millbank, Parkhurst (a boys' prison until 1864), Pentonville, Woking (closed in 1889), and Wormwood Scrubs. Brixton, Millbank, Pentonville, and Woking were not located near appropriate open-air public works. Convicts in Borstal could work on Chatham dockyard.

33 For the legalities of chain gangs in the United States, see E. S. Stanford, 'The Propriety and Constitutionality of Chain Gangs' (1997) 13 Georgia State Law Rev. 1155.

34 Technically at this time 'Bofers swan-drop breach loading' cartridges; this was before the adoption of what were called Boxer cartridges.

35 At mutinies at Chatham in 1861 and Parkhurst in 1864, civil guards opened fire on the ringleaders. See Wilkinson, op. cit., n. 26, at p. 217. There may have been firing at Portland in 1864. 
of simple escape. The Home Secretary referred the matter to the Law Officers, Sir Alexander J.E. Cockburn and Sir William P. Wood. They advised that firearms could lawfully, if necessary, be used 'in the event of a combination among convicts and of an overt act of mutiny in order to overpower the officers and break out of the prison', and this whether this occurred inside or outside the prison. ${ }^{36}$ But they had grave doubts as to whether a sentry or warder could lawfully fire on a prisoner who was making an escape without engaging in violence, since this would not amount to the felony of prison breach, but merely to a misdemeanor. So they advised against firing, and recommenced that if such a power was needed legislation should be sought. This meant that warders could not shoot at a convict serving a sentence of penal servitude who simply ran off. The Home Office was unhappy with this, and reopened the question, pointing out that the prisoners in relation to whom the opinion had been sought were all under sentence of transportation, and for them to be at large was a felony. ${ }^{37}$ The Law Officers said that they knew this, but it made no difference to their opinion, adding that:

... to say that felony unaccompanied by violence may be prevented by the death of an offender is a proposition which cannot be supported either on authority or principle.

Does 'principle' mean moral principle or legal principle or both? It is not possible to say. So Jebb issued a circular to the Governors of Convict Prisons which broadly followed this opinion, and, so far as simple escapes were concerned, said:

In cases of Prisoners seen to run away, or to make an attempt to escape there is so little chance of their success, when an immediate pursuit can be made, that no prison officer or sentry would be justified in making use of Fire Arms, and you will take care to impress this both upon prison officers and sentries. ${ }^{38}$

This circular was issued to Parkhurst, Dartmoor, and Portland prisons on 19 February 1852. Additional arms would be provided, and special ammunition was being made. The weapons were only for self-defence; escaping prisoners were not to be fired upon. ${ }^{39}$

After three escapes from the hulks, Jebb raised the matter again in March 1852. These escapes would probably not have occurred but for the fact that it was now generally known that sentries could not fire upon escaping convicts:

I am no advocate for such an extreme measure as that of firing upon a man, but I am satisfied that if the power of doing so existed and was generally believed, as was the case before the issue of the recent Order, it would very seldom or never be required to be resorted to. ${ }^{40}$

36 PCOM 9/98 and HO 45/17321.

37 Under the Statute of 5 Geo. IV c. 84 s. 22.

38 PCOM 9/98, circular of February 1952.

39 Standing Orders for the Convict Prisons, cited in Wilkinson, op. cit., n. 26, at p. 215.

40 Letter of 25 March 1852 to H. Waddington, the Permanent Under-Secretary. 
The new Law Officers, Sir Frederick Thesiger and Sir Fitzroy Kelly, differed from their predecessors. Firearms could be used against a convicted felon who was attempting to escape, but not against those merely convicted of misdemeanors:

All the authorities seem to agree that if a felon flies from Justice and is killed by an officer in pursuit the homicide is justifiable if he could not be otherwise overtaken.

They argued that for felons to flee, whether from within the prison or from a working party outside the walls, constituted the felony of prison breach, and so such a felon could be fired upon, and if death resulted this would be justifiable homicide. The shooting was thus a mechanism for preventing the completion of a felony. But the same rule did not apply to misdemeanants. So their conclusion was:

... that it is lawful to shoot at a felon convict if his escape cannot otherwise be prevented, but not at a person confined under sentence of transportation for a misdemeanor. ${ }^{41}$

This opinion applied the doctrine as to the use of deadly force to bring a felon to justice to the legitimacy of using deadly force in order to prevent convicted felons escaping. In the papers the transition is nowhere emphasized. A new circular was issued, making it clear that guards were entitled to fire on escaping felons if there was no other way of stopping them. ${ }^{42}$

The issue was raised yet again in 1864, and the law officers, Sir Roundell Palmer and Sir Robert P. Collier agreed that firearms could lawfully be used against convicted felons who attempted to escape so long as their escape could not be prevented by less severe means. But the reasoning was different, since they did not rely on the argument that the escape, or attempt to escape, constituted a new felony ('being at large' or 'prison breach'):

It is perfectly settled law that 'if a felon flees, and he cannot otherwise be taken, if he be killed it is no felony .... ${ }^{43}$

In 1863 the matter was again raised with the Law Officers in Ireland, Thomas O'Hagan and James Lawson, in response to an inquiry from the Governor of Spike Island, and again in 1865, and the distinction between felons and misdemeanants maintained, though it was suggested that if a group comprising both felons and misdemeanants was fired on, and a misdemeanant rather than a felon was killed, this would be justifiable homicide, but presumably not if the group comprised only misdemeanants. There was discussion of possible legislation, but Sir Henry Thring, at this time Home Office Counsel, advised, that:

41 Opinion of 28 April 1852 in PCOM 9/98. See, also, HO 45/9520/24968A (Law Officers' Opinion 282).

42 Cited in Wilkinson, op. cit., n. 26, at p. 215 as dated 19 May 1852.

43 Relying on Hale, op. cit., n. 19. 
... no alteration of the law would practically be of much use except an express enactment that sentries may fire on prisoners endeavouring to escape from convict prisons and I greatly doubt whether such a measure could be carried. ${ }^{44}$

In 1880 the matter was again raised with the Law Officers, now Sir Henry James and Sir Farrer Herschell, who agreed in principle with the opinion given in $1864 .^{45}$

In reliance on the opinion of 1852 , the guards in convict prisons, who at Dartmoor were from 1854 civil guards, ${ }^{46}$ were given firearms, and a Standing Order was issued, based on the Law Officers' opinion. The weapons then in use appear to have been loaded with buckshot. In 1859 a new type of ammunition was issued; this would be some form of buckshot cartridge, though nothing else is known about it. A Standing Order of that year stated that the aim of firing was to induce the felon to stop; the first shot should be aimed wide, and thereafter fire should be low. ${ }^{47}$ This order was sent to Portland, Portsmouth, Chatham, Millbank, Pentonville, Lewes, and Woking prisons as well as to Dartmoor.

As we have seen the weapons in use at Dartmoor in 1868, and probably earlier, were Snider Enfields. In 1868 the War Office adopted a new buckshot cartridge, known as the Buckshot Snider Mark I, specifically for use in convict prisons and for riot control. ${ }^{48} \mathrm{An}$ article in The Engineer discussed its value in riot control:

... the effect of the buckshot - being probably limited to about 150 yards at the most - would be confined to the locality of the disturbance, and the lives of individuals half a mile away would not be endangered. Again, as concerns the rioter themselves, a very wholesome punishment might be administered at about 100 yards with comparatively little risk of life being sacrificed, although blood might be drawn, cries elicited, and very great moral effect produced. ${ }^{49}$

At close range such cartridges were certainly lethal.

How often firearms were in fact used between 1852 and 1880, and with what results, is not recorded. ${ }^{50}$ From Basil Thomson's account of Dartmoor it appears that before his time violent assaults on warders were not uncommon, and there were numerous escapes. A few prisoners even managed to get off the moor and were never recaptured, such as Charles Webster, who escaped on 10 December $1850,{ }^{51}$ Barrow, who escaped on 8 November 1852, and the juveniles Bell and Robins who escaped on 1 April 1860. Thompson records that some were fired upon, such as Warburton, who ran

44 Letter of 11 March 1868 in PCOM 9/98. See, also, HO 45/9600/99316.

45 Opinion of 15 December 1880.

46 For their history, see J.E.Thomas, The English Police Officer since 1830. A Study in Conflict (1972). They were formed in 1850 and disbanded in 1919.

47 See Wilkinson. op. cit., n. 26, at pp. 216-17, citing Standing Order 69.

48 See B.A. Temple, The Boxer Cartridge in the British Service (1977) 55 and ff.

49 Engineer, 16 June 1871.

50 See memorandum of HO 45/9743/A55944.

51 With two companions, John Brodrick and John Thompson, who were recaptured. 
from a working party on 21 December 1854 and was shot in the thigh, and John Cooper, who ran on 12 May 1854, and was hit by a slug in the back, though he was apparently not killed. ${ }^{52}$ On this occasion a piece of shot also hit one of the children of a civil guard, who happened to be in the area at the time. Rhodes mentions the case of one Scott who was fired at but not hit in $1881 .^{53}$

The legalities of shooting escaping felons arose in a most peculiar form in 1873 in connection with the escape of two felons from the convict prison in Gibraltar. ${ }^{54}$ This was under the supervision of the Directors of Convict Prisons. ${ }^{55}$ Both had been convicted of manslaughter. On 8 July 1873 they set off in a boat, and two warders who were armed with revolvers pursued them and fired at them. One, Ansel Larkin, was killed; the other, one Gorman, was recaptured uninjured. The coroner's jury found a verdict of wilful murder against the two warders. They were charged with murder and the matter then came before the magistrates, who conducted a preliminary enquiry and threw out the charge of murder; the warders had merely performed their duty. This did not however discharge the indictment for murder arising from the verdict of the coroner's jury. In England the indictment would have come before a Grand Jury. But in Gibraltar the Attorney-General performed the function of the Grand Jury, and he took the view that the case should go before a jury. The two officers were released on bail on application to a judge. The proceedings were now complicated by the illness and incapacity of the Attorney General. His deputy, acting on advice from the Colonial Secretary, the Earl of Kimberley, ${ }^{56}$ who had consulted with the Home Office, entered a nolle prosequi. So the proceedings came to a close. This was the nearest a court ever came to adjudicating upon the shooting of an escaping felon.

Thereafter incidents in which escaping convicts were shot at nearly all occurred at Dartmoor, though there were armed guards and outside working parties at other convict prisons. ${ }^{57}$ There was an incident in 1900 at Borstal, when the felon Francis Moore was shot at when attempting escape from a working party; he received two superficial wounds. ${ }^{58}$ Presumably the reason why all other cases occurred at Dartmoor was because of a paradox. The combination of moor and weather encouraged attempts to escape, notwithstanding the fact that the chances of evading capture were, because

52 Rhodes, op. cit., n. 17, at p. 118 has this case, referring to the victim as James Cooper.

53 See id., p. 124.

54 This was a hulk.

55 The case is covered in $\mathrm{HO} 45 / 9347 / 24968$.

56 John Wodehouse, who became the first earl.

57 In 1881 the convict prisons were Borstal, Brixton, Millbank, Parkhurst (which had been a boys' prison until 1864), Pentonville, Woking (closed in 1889), and Wormwood Scrubs.

58 See HO 45/17321. Borstal Prison in Kent was at this time a convict prison, not an institution for young offenders. 
of moor and weather, almost non-existent. And the civil guards could do little else but fire upon convicts who ran. ${ }^{59}$ Presumably the introduction of mounted guards was an attempt to reduce the need to use firearms. They were in use when Basil Thomson was at Dartmoor, ${ }^{60}$ and as we have seen, a mounted guard features in The Hound of the Baskervilles, first published in 1901-2, but only as part of a cordon.

A Home Office memorandum of $1922^{61}$ records that, since 1880 , there had been only three incidents, all at Dartmoor, in which escaping felons had been shot and killed. There is no mention of earlier deaths and, as we have seen, Thomson in his book on Dartmoor says nothing about any deaths, nor does he mention floggings. ${ }^{62}$ Deaths of convicts were investigated by the coroner, sitting with a jury. The juries exonerated the guards concerned.

In the first case, in 1880, the prisoner who was killed was Thomas or, according to the Times, James Bevan. ${ }^{63}$ The incident occurred on 12 November. Bevan was not a nice person. He was serving a sentence of 25 years penal servitude for roasting an old lady over a fire; she had refused to reveal where her money was concealed. He would, almost certainly, have been flogged. He was one of 74 convicts working in the quarries, his job being to drill holes in stone, in preparation for blasting. The convicts were guarded by the civil guards, who had rifled carbines. There had been a plot amongst the prisoners, or some of them, to overpower the guards and escape; there was a dense fog. At the end of the day the convicts were ordered to fall in to march back to the prison. Bevan came up behind the senior warder, John Westlake, and hit him with a 20-pound jumper, the tool used to drill the holes. Westlake, who was armed with a sword, was unable to draw it, and ran towards the smith's shop, which was in the quarries, calling out to the other warders and guards to tell Bevan to stop. Bevan, finding that he was receiving no support from the other convicts, obediently fell in. Shortly after this he and another convict, O'Brien, changed their minds, and ran. Bevan would know that he was virtually certain to be flogged a second time with the cat-o'-nine-tails for the assault. So his only hope of escaping a flogging was to run. Both Bevan and O'Brien were shot; the latter survived, but had his leg broken, but Bevan died. Six guards fired, aiming only to wound. At the inquest William Lord, a civil guard, explained that:

The rules are that first, sentries will allow no prisoner to escape, using their arms, if necessary, to enforce their orders; second, they are required to render immediate assistance in the event of an officer being assaulted in the vicinity of their posts, making use of their arms if necessary. The Governor of the Prison has stated that these rules were issued in conformity with the standing

59 The civil guards lasted until 1919.

60 See Thomson, op. cit. (1925), n. 5, at p. 99.

61 PCOM 9/223, and see, also, the memorandum of 1897 in HO 45/9743/A55944.

62 The Prison Act of 1898 permitted flogging of prisoners as a prison disciplinary measure only for gross personal violence to warders or mutiny.

63 The Times, 13 and 19 November 1880. See, also, Rhodes, op. cit., n. 17, at pp. 164-5. 
rules of the Home Office. The Coroner here mentioned that not only were they in accordance with the rules of the Home Department, but they were also in consonance with the common law of the country.

Lord probably killed Bevan, and he explained that:

If I had not fired he would have been out of my sight in a minute. There was a very dense fog. Other shots were fired besides mine.

The jury found a verdict of justifiable homicide. ${ }^{64}$

Shortly after this, a decision was taken that no more misdemeanants should be sent to Dartmoor, lest, by administrative error, they were shot and killed. So thereafter, until policy changed the whole population of Dartmoor consisted of shootable convicts.

In 1882, according to the Home Office memorandum of 1922, one such felon convict, William Murray, attempted to start a mutiny, and seized a warder's weapon. It went off and another warder fired his. Murray was killed. This incident is reported in the Times, but not as involving a shooting. ${ }^{65}$ The death is mentioned in the medical offers report for that year. This recorded for 1882-3 two accidental deaths, one by gunshot wounds. The verdict must have been one of accidental death. ${ }^{66}$

In 1896 three convicts, John Martin, ${ }^{67}$ Ralph Goodwin (alias John Hammond) ${ }^{68}$ and William Carter, ran in thick fog on Christmas Eve, the day on which Basil Thomson arrived to become Deputy Governor. ${ }^{69}$ Carter was serving a sentence of twelve years penal servitude for robbery with violence, and he had been given twenty-five strokes of the cat-o'-nine-tails earlier in the year. The escaping convicts were warned that they would be shot at if they did not stop. John Martin was seized and overpowered by a warder, receiving a head injury in the process. Goodwin managed to get clear of the moor. In Tavistock he stole half a roast turkey and two plum puddings, so at least he got a Christmas dinner. He was recaptured on 26 December.

William Carter had been killed. Two warders had fired at him, and one Rogers killed him. The weapon used was a Snider Enfield charged with buckshot; the cartridge would have either been the Mark I or the Mark II,

64 The case is briefly mentioned in an extract from the Governor's Report in the Report of the Directors of Convict Prisons for 1880-1, PP (1881-2) LII: 'On the 12th November two prisoners attempted to escape from the quarry, as the parties were parading for marching in; refusing to stop when called on, the Civil Guard fired, both prisoners being hit; one prisoner subsequently died.'

65 The Times, 5 October 1882.

66 See PP (1883-4) XXVIII 1, 'Report of the Directors of Convict Prisons for 1882-3'.

67 Serving 12 years for manslaughter.

68 Serving five years for burglary and related offences.

69 This incident is very fully documented in HO 45/9743/A55944, cited by W.J. Forsythe, Penal Discipline, Reformatory Projects and the English Prison Commission 1895-1939 (1991) at 73 and 77. See, also, the Times for 25, 26, and 28 December 1896; Thomson, op. cit. (1937), n. 5, at pp. 190-1; Rhodes, op. cit., n. 17 , at pp. $125-8$. 
which had been introduced in 1873 , and which contained 32 pellets weighing slightly less than the Mark I -416 grains. The charge was also slightly less at 54 grains. ${ }^{70}$ From such a rifled weapon. the shot did not spread widely, and was therefore more lethal if the convict was hit. The pattern of his wounds covered seven by four inches. He was hit in the lower back when jumping off a wall, and the file contains a plan from which the exact location of this macabre event can still be identified. Questions were asked in the House of Commons, one questioner being Michael Davitt, at this time member for County Mayo. As a member of the Fenian Brotherhood he had, in 1870, been sentenced to fifteen years penal servitude for treason-felony, serving most of his time in Dartmoor. ${ }^{71}$ The Home Secretary, Sir Mathew Ridley, explained that the right to use firearms was:

... affirmed by successive opinions of the law officers of the Crown ... The right to use firearms, in the last resort, cannot I think be safely dispensed with; but I am considering whether any alterations can be made in regard to the weapons used or otherwise, so as to diminish as far as possible the chance of causing death. ${ }^{72}$

He agreed to lay on the table the standing orders governing the use of firearms.

This was done in February $1897 .^{73}$ They did not purport to lay down any precise rules, but rather principles of guidance, and order 84 provided:

In the case of a convict who is seen to run away, or to make an attempt to escape, there is so little chance of success when an immediate pursuit can be made, that the use of firearms would not be justified; but in the case of absolute necessity it is lawful to shoot a felon convict if his escape cannot otherwise be prevented. (emphasis added)

The next order provided that:

The object of firing being mainly to induce a convict to stop whilst in the act of effecting his escape, it would be advisable that the first shot, at least, should be wide of the mark, and if it should be necessary again to fire, that the aim should be low, which would avoid the danger of wounding a vital part, and would, at the same time, be most effective in causing him to desist from his purpose.

The order went on to instruct that convicts should clearly know that they might be fired upon.

Before 1897 there were other occasions, in addition to those mentioned by Basil Thomson, when Dartmoor convicts were fired upon, as happened to

70 This cartridge was much used to maim or kill Africans in the Ashanti Wars.

71 (1841-1906). He was released on ticket of leave in 1877, and imprisoned again in 1881. In spite of his radical views he was a highly respected member, and was active in prison reform.

72 M. Ridley, 45 Parl. Debs. col. 188 (21 January 1897).

73 See 'Copy of all Standing Orders and Instructions Regulating the Conduct of Officers in Convict Prisons in the Event of a Prisoner in their Custody attempting to Escape', PP (1897) 73, 241. 
three men, Samson, Kelly, and Samuels in January 1874, who had made a run for it in dense fog. All were injured; how severely is not recorded, but none died. ${ }^{74}$ There may well have been other cases.

A consequence of the killing of William Carter, and Home Office feelings that killing escaping convicts was really going too far, was that experiments were carried out by Basil Thomson as to what cartridges would be best suited to stopping escaping convicts without causing fatal injuries. Thus, administrative arrangements were used to soften the crudity of the common law rule. E. Ruggles-Brise, the chairman of the Prison Commissioners wrote a memorandum saying that warders were not to use revolvers unless in selfdefence, and that shots from carbines should be fired so that 'there shall be no danger of taking effect fatally'. ${ }^{75}$ Unrifled weapons were introduced, which increased the spread of the shot, and the charges reduced. The weapons then in use could not readily be converted to smooth-bore weapons, so Martini-Henry carbines were introduced instead, but probably only as an interim measure, and in Thomson's time the weapons were Enfield Sniders. ${ }^{76}$ A new cartridge was approved for use in the prison service in $1898 .^{77}$ In 1902, the charge of powder in the cartridges was set at 50 grains, with 200 grains of AAA shot; the cartridge approved in 1898 had the same charge but there may have been 300 grains of shot. ${ }^{78}$ In a Times report of an incident in 1901 it was said that:

The prison warders complain that the cartridges with which they are supplied are loaded with such weak charges of powder as to be entirely useless.

The shot used was no longer properly called buckshot, since the size of the pellets was too small.

Between 1896 and 1912 there were, according to the Home Office file of 1922, four cases at Dartmoor where felons were wounded, one severely. These incidents are not all fully documented. ${ }^{80}$ In 1901 a prisoner referred to simply as C was shot in the eye. ${ }^{81}$ In July 1909 Henry James was fired on after three warnings, and was hit by three pellets without serious injury. In 1911 Albert Lewis and Perceval Bruce tried to escape from the quarries. The civil guard fired a warning shot and then fired at Bruce, causing two

74 The Home Office file was 34,422 , but does not seem to have survived.

75 Forsythe, op. cit., n. 69, at pp. 73 and 77.

76 A buckshot cartridge existed for the Martini-Henry; see Temple. op. cit., n. 48, at pp. $102-3$.

77 See id., at p. 59.

78 Thomson says no. 5 shot (op. cit. (1907), n. 5).

79 This incident is reported in the Times of 2, 4, and 9 November 1901.

80 The Times, 15 July 1899 records an attempted escape by Joseph Dell; a weapon was fired into the air, and he was soon recaptured. On 13 October 1908 it was reported that Ernest Wilson had escaped and been fired at, but there is no report of a wounding. There is some information in $\mathrm{HO} 45 / 17321$.

81 Rhodes, op. cit., n. 17, at p. 130. The pellet was extracted; presumably the convict did not lose his sight. 
superficial wounds in the legs, and one deeper wound, but the injury was not severe. The other convict was recaptured after four or five days. ${ }^{82}$ In April 1912 two convicts, William Warner and James Bannister, ran off in heavy rain and mist, and were fired on after warning shots; both were wounded, Warner severely, pellets entering his abdomen. It was feared that he might die. $^{83}$ In 1901, S.W. Kay, a misdemeanant who was serving time in Parkhurst, was shot. His injuries were trivial and his petition for compensation was turned down. The Home Office in 1922 had no record of all the occasions on which guards opened fire without causing death or injury, and there may have been other incidents which could be located in local newspapers but they are not indexed. ${ }^{84}$

So far as Dartmoor and indeed other convict prisons are concerned there was an important change in policy in 1901. Previously, after a decision in 1880 or 1881 , the non-shootable misdemeanants serving sentences of penal servitude had been held in Parkhurst. But in that year it was decided that they might be sent to all convict prisons, including Dartmoor. But they were not to be allowed to work outside the walls of the prison. The thinking was that if they joined parties of felons guarded by armed officers, they might be unlawfully shot, and if they were employed in working parties not accompanied by armed guards, they might escape. That the risk of accidentally shooting a non-shootable misdemeanant was real was brought home to the officials in 1901 by the incident involving the shooting of S.W. Kay. It may be that it was this incident which led to the decision not to allow misdemeanants to work outside the walls. ${ }^{85}$

In the Times there are quite a number of reports of escapes from Dartmoor in which no shooting took place. Thus, in 1889, John Morgan escaped from inside the prison down a knotted blanket. ${ }^{86}$ In June 1901 Walter Silvester and Fergus Frith escaped from work in the blacksmith's shop; they were hunted down by the local populace, using horses and dogs, and of course by the warders, and the incident seems to have provided entertainment similar to that provided by fox or stag hunting. ${ }^{87}$ Indeed, in the case of Albert Lewis, in 1911, an incompetent pet bloodhound was borrowed from a solicitor, Mr. Lloyd, who was visiting the area on vacation. It sniffed his cell and then set off enthusiastically in the wrong direction. Lewis was in fact not far from the prison at the time, ${ }^{88}$ but the hound negligently or sympathetically failed to

82 Times, 27-30 September 1911. According to this report Lewis' clothing was punctured by shot, but he was not wounded.

83 PCOM 8/178

84 The Times is the only paper from this period with a comprehensive index.

85 The case is mentioned briefly in HO $45 / 17321$.

86 Times, 4 and 5 January 1898.

87 Times, 14, 15, 17, 18 June 1901. This incident may have coincided with Conan Doyle's visit to the Duchy Hotel in Princetown.

88 Times, 27 and 30 September 1911. 
notice this. ${ }^{89}$ Most escapes took the classic form of flight in dense fog. Thus, in June 1907, Thomas Ellis and Alfred Parrish escaped from the quarries in such conditions. ${ }^{90}$ Parrish, soon recaptured, tried again with another convict, William Wilks, in October 1908. He had been made to wear chains for six months and had already lost all marks which would have gone to reduction of his time inside. ${ }^{91}$

The authorities reacted to escapes by telegraphing information to local post offices and police stations, by establishing a cordon around the moor, and by direct pursuit by warders or guards on foot or on horseback. Rewards were also offered for information or capture. To have any hope of success the convict had to obtain food and clothing, and could only do so by burglary, thereby leaving a trail. Escaped convicts commonly soon had no idea where they were, or what direction to follow. Ralph Goodwin, for example, wandered in circles for some hours and found himself back near the prison. Cold, exhausted, and usually starving, they were virtually always recaptured within a few days. Some ended up in the prison hospital, like Fergus Frith, who caught pneumonia on his escape in 1901, or Albert Lewis, who was in a state of collapse when apprehended by a Mrs. Haggenden attempting to steal food. He told a no doubt startled Mrs. Haggenden: 'All right Missus. I am done up and fed up. I won't harm you.'

The treatment of a recaptured convict was not agreeable. He was made to wear a special uniform, partly coloured bright yellow, and was punished with a period on bread and water. He suffered loss of remission of his sentence and, for six months, by way of precaution only, it was said, made to wear chains or cross irons, variously said to weigh four and a half, six, and nine pounds. In addition a prisoner who committed offences when on the run could be tried for this and receive a further sentence, and in cases of violence, this might include corporal punishment. ${ }^{92}$ Chaining and special clothing were discontinued in 1922 and 1924 in the case of simple escapes. ${ }^{93}$

All this being so, it might be thought that there was no need to use firearms at all: all that was needed was to cordon the area and wait for disorientation, starvation, and the weather to deliver up the convict. But a convict at large caused considerable local fear. Conan Doyle makes much of this:

There's a convict escaped from Princetown, sir ... The farmers about here don't like it sir, and thats a fact ... This is a man that would stick at nothing. ${ }^{94}$

89 Rhodes, op. cit., n. 17, at p. 146 states that bloodhounds were first used in 1931, and provides pictures.

90 Times, 5 and 6 June 1907.

91 Times, 7, 8, 9 October 1908.

92 See HO 45/24539, case of Thomas Ellis and Alfred Parrish in 1907.

$93 \mathrm{HO} 45 / 11077 / 407837$. The change was provoked as a result of an escape by one Arthur Conwy.

94 This is said by Perkins, who drove Drs Watson and Mortimer to Baskerville Hall. 
Home Office officials believed that the possibility of being shot operated as a powerful deterrent, as no doubt it did.

The use of firearms had, since 1851, been governed by standing orders; by 1922 the relevant order was S.O. 661 (2). This was, so far as escapes are concerned, unchanged since 1896, and was based upon the original circular by Jebb. ${ }^{95}$ The order still took the form of instructions which were to 'serve for guidance without laying down any precise rules'. Under the regulations and administrative arrangements which were in force in 1922, introduced after the death of William Carter, no prisoner had been fatally shot.

During the 1914-18 war the prison population dropped. So Dartmoor was closed as a convict prison in February 1917, and used for conscientious objectors. ${ }^{96}$ By 1919 it was again being used as a convict prison. In 1920, according to the Times, there was a scheme to use the prison simply to house a Borstal Institution, the convicts being moved to Portland, and the armed guards abolished. ${ }^{97}$ But with the prison population rising it remained in use as a convict prison, and was refurbished in $1921 .^{98}$

In 1922 the Home Office was confronted with a problem over some Irish prisoners. During the First World War under the Defence of the Realm Acts (DORA), it was possible to try rebellious Irish nationalists in Ireland by courts martial. The war only officially ended in 1921. The troubles continued, and in order to continue this practice, the Restoration of Order in Ireland Act 1920 (ROIA), was enacted, and a code of regulations introduced on 13 August $1921 .^{99}$ Persons convicted of ROIA offences by court martial were moved to England to serve their sentences. In 1922 some were in Wandsworth Prison; they were not released in response to the Anglo-Irish Treaty of 6 December 1921. Some wanted to be transferred to a convict prison and be allowed to work in the open air outside the prison. At this time, as we have seen, regular misdemeanants were not allowed to work outside the walls, and they too, like the Irish, viewed this as a grievance. If the Irish prisoners were not to be regarded, for shooting purposes, as convicted felons,

95 The 1927 version is in PCOM 7/93, and for escapes 1,193 (2). (2) (c) and (d) read: In the case of a convict who is seen to run away, or to make an attempt to escape, there is so little chance of success, when an immediate pursuit can be made, that the use of fire-arms would not be justified, but in case of absolute necessity, it is lawful to shoot at a felon convict if his escape cannot otherwise be prevented.

The object of firing being mainly to induce a convict to stop whilst in the act of effecting his escape, it would be advisable that the first shot, at least, should be wide of the mark, and if it should be necessary again to fire, that the aim should be low, which would avoid the danger of wounding a vital part, and would at the same time be most effective in causing him to desist from his purpose.

96 PCOM 7/12.

Prisoners were to be told of the risk of being shot.

97 The Times, 24 July 1920.

98 This is noted in Cmd. 5153, op. cit., n. 11.

99 For an account, see A.W. Brian Simpson, In the Highest Degree Odious: Detention Without Trial in Wartime Britain (1992) at 27-33. 
there were two problems. How were they to be deterred from attempting to escape? And if an outside parties comprised both shootable and nonshootable convicts, then would it be necessary, though administratively very inconvenient, to divide the working parties up into shootable and nonshootable groups? For if they were all mixed together warders could hardly be expected, when a prisoner made a run for it, to remember whether he was a shootable or non-shootable prisoner. Yet it seemed churlish to prevent the Irish prisoners from working in the open air simply because they could not be shot. Indeed if they were, legally speaking, non-shootable, the law appeared to discriminate against them. Why should they be treated less generously than felons who enjoyed the benefits of shootability - the chance to engage in agreeable outside work?

So an attempt was made to reopen the whole issue with the Law Officers, Sir Ernest M. Pollock and Sir Leslie Scott. The submission to them was accompanied by a memorandum which in effect argued that the distinction between what could be done to convicted felons and what could be done to convicted misdemeanants was not justified by the legal authorities, and in any event made no sense. It was quite clear that the prison authorities, and individual warders, were under a stringent duty to prevent escapes:

In law the use of fire-arms for the purpose [of preventing an escape] does not differ from the use of any other weapon except that as a carbine is more likely to cause death than a sabre or a truncheon, it must not be used so freely. It is submitted that if a convict is killed by a prison warder in attempting to escape, the question for the jury would be whether the warder had done more than was reasonably necessary to prevent an escape, and this would be the same whether the warder had used a fire-arm or some less lethal weapon.

The memorandum argued that the distinction drawn between those serving sentences for felonies and those for misdemeanors was '... more a theory of the text books than an active principle of law enforced by the Courts'. There had never been a legal decision, and in the case of William Carter in 1896, the coroner had made no reference to a distinction between felonies and misdemeanors.

The Law Officers nevertheless advised that the distinction drawn by their predecessors remained good law. ${ }^{100}$ They thought however that persons convicted by courts martial, although not technically convicted felons, could nevertheless be treated as such for shooting, if the offence for which they had been convicted was in fact a felony. What was critical to shootability was the commission of a felony, not conviction. They agreed that the law made little sense, and suggested that it might be changed by legislation.

The Home Office officials were in something of a quandary as to what to do next. ${ }^{101}$ Leslie Brass, minuted that:

100 The opinion is in LO $3 / 589$.

101 There is a history of the matter in PCOM 4/405. 
Firearms have so rarely to be used against convicts that it is worth considering whether misdemeanants might not be allowed to work in the open with felons - the chance of one being shot is very remote, and the chance of the warder who shot him being prosecuted for doing so, still more remote.

Sir Erneley Blackwell wrote:

I am inclined to agree that in practice the distinction between felons and misdemeanants for purposes of work outside the wall - might be safely disregarded. Possible the misdemeanants could be kept in parties separate from the felons as so be less likely to be shot...

Sir John Anderson, the Permanent Under-Secretary, asked what the instructions to the warders were; he was referred to Standing Order 661 (2), J. R. Farrant adding:

It is also the practice - not mentioned in the orders - for officers to, if possible [to] shout a warning before firing.

Blackwell then discussed the whole issue with Maurice L. Waller, who had succeeded Sir Eric Ruggles-Brise as Chairman of the Prison Commissioners in 1921, and changed his view:

... I think it is better to leave the present practice as it is. It is hard on the misdemeanants but it can't be helped.

Anderson agreed, and A. Locke suggested that legislation might be considered:

Legislation might be possible in connection with any legislation for "prison reform', on the ground of hardship to misdemeanants.

But no such legislation was introduced, and so it was that the Irish prisoners, and other misdemeanants, were denied the opportunity to work outside the convict prisons. This remained the position until 1930.

By January 1930 working parties guarded by armed men survived only at Dartmoor and possibly Parkhurst, though weapons were held in other convict prisons against the risk of mutiny. ${ }^{102}$ The Home Office thought armed guards were still essential. Blackwell minuted in 1931:

I have no doubt that fear of being plugged from behind acts as a very strong moral deterrent. It very seldom has to be put in force. If it were abolished it would be necessary either to keep convicts within the walls or to chain them together when working outside. ${ }^{103}$

So Dartmoor continued as the prison with the armed guards, and some concern arose over its becoming a tourist attraction, rather resembling a zoo; in summer up to 300 or 400 people would sometimes arrive to watch the convicts march out to work. ${ }^{104}$ At about this time the use of armed guards at Parkhurst must have ceased.

102 This appears from HO 45/17321. See, also, PCOM 9/98.

$103 \mathrm{HO} 45 / 17321$.

104 See PCOM 9/2, dealing with the protection of Dartmoor prisoners from public gaze, 1926-36. See Thomson, op. cit. (1907), n. 5, at p. 220. 
In 1930, with the liberal Sir Alexander Maxwell as Chairman of the Prison Commissioners, ${ }^{105}$ there was a change in policy. Misdemeanants, carefully selected as having longer to serve than remission to forfeit, were to be allowed to work outside the walls, and the guards were told not to shoot anyone unless certain that he was a felon. No blame was to be attached to an officer who did not fire. The Standing Orders then in force provided that 'in case of absolute necessity it is lawful to shoot at a felon if his escape cannot otherwise be prevented' and recommended that at least the first shot should be wide of the mark, and subsequent shots fired low. The order had been substantially unchanged since $1851 .{ }^{106}$ The arrangements for misdemeanants were reviewed in 1933. Working parties of felons were by now additionally guarded by mounted officers armed with .45 revolvers. The revolvers must have been provided only for self-defence. Unmounted guards at this time still carried Enfield Sniders and had orders to fire high first, and then low. The use of bayonets had been abandoned some years earlier; there is no evidence that any convicts were ever bayoneted. Reliance on firearms was reduced in 1934 by abandoning the practice, which then existed in Parkhurst and Dartmoor, of routinely arming night patrols with .45 revolvers for self-defence. ${ }^{107}$ Revolvers were now to be entirely replaced; both the mounted guards and the night guards were to be issued with heavy lead-loaded batons. ${ }^{108}$ The carbines were to be carried unloaded, to be loaded when needed.

As for outside parties, a scheme was devised which would have kept felons and misdemeanants in different parties, and inform warders of the location of misdemeanant working parties. But there were second thoughts after this plan had been discussed between the Governor of Dartmoor and the new Chairman of the Commissioners, Sir Harold Scott; ${ }^{109}$ there was a risk of a misdemeanant being shot by mistake for a felon. So it was decided in future never to allow misdemeanants to work outside the walls, and to send as few as possible to Dartmoor. ${ }^{110}$ They continued to be excluded from outside parties until 1947 when Dartmoor was brought back into use as a convict prison after the war.

There was a serious riot in Dartmoor in January 1932. ${ }^{111}$ The riot was quelled by police from Plymouth, and was the subject of a Report by Mr.

105 He was appointed in 1928.

106 Order reproduced in a memorandum by Maxwell in PCOM 9/98. See also PCOM 7/ 193.

107 The Governor of Chelmsford joined the discussions, and did not want to have revolvers in his prison.

108 Wilkinson, op. cit., n. 26, at p. 219 states that Webley revolvers were carried by mounted patrols on Dartmoor until 1957. I think this must refer to the issue of revolvers to mounted officers involved in the pursuit of escaped felons.

109 Chairman 1932-9.

110 See PCOM 9/405 and PCOM 9/98 for this and what follows.

111 The Home Office files on the riots, HO 144/20647 and 20648, have recently been opened. They confirm the identity of the severely injured Mitchell. 
Herbert du Parcq K.C. on the Circumstances Connected with the Recent Disorder in Dartmoor Convict Prison. ${ }^{12}$ Du Parcq was assisted by one of the Prison Commissioners, Alexander Patterson. Certain officers, armed with Enfield Sniders guarded the walls of the prison during the riot, and fired on a number of occasions, but only so as to prevent escapes, or so it was claimed. In addition, some of the police who entered the prison and suppressed the riot, mainly by a baton charge, were similarly armed, and there were shots fired by them, resulting in one convict being wounded. One entirely loyal convict was shot by mistake, and six others in all were wounded, one severely, but there were no fatalities. According to Macartney, who nursed him in Parkhurst, the severely injured convict's name was Mitchell:

Mitchell was on the roof, deriding and thumbing his nose at the jailors. So they shot him. Now he is dumb and paralyzed. ${ }^{113}$

His injuries were partly directly caused by gunshot, and partly from injuries received when he fell off the roof. At the time of the completion of du Parcq's report, it was thought that he might die. Du Parcq's report was a miserably inadequate piece of work, and had virtually nothing to say on the use of armed guards.

Given the risk of riots, Dartmoor and Parkhurst retained considerable stocks of weapons. In Dartmoor in about 1934 the armoury contained 64 carbines (these would Snider Enfields), 13 revolvers, and 2,500 rounds of ammunition. Single officers with outside working parties continued to be armed with carbines on the authority of the Governor. The mutiny, in which the convicts had for a while secured complete control of the prison, naturally provoked concerns over security, and the standing order for the use of firearms were revised. For escapes the new orders were somewhat simplified and redrafted to provide strict rules, rather than general guidance based on principles:

8. Escape or attempt to escape by convicts outside Dartmoor Prison.

(a) Misdemeanants will not be employed outside the walls.

(b) In case of absolute necessity it is lawful to shoot a felon (but not a misdemeanant) convict if his escape cannot otherwise be prevented.

(c) If it becomes necessary to shoot, the first shot should be aimed high above the escaping convict, and if a second shot is necessary it should be aimed low so as to avoid the danger of wounding a vital part. ${ }^{114}$

Arrangements were also introduced to ensure that warders received regular practice in the use of firearms.

During the Second World War, Dartmoor was used for recidivists until 1942, when the convicts were moved elsewhere, and it was thereafter used as

112 Published as Cmd. 4010 in February 1932.

113 Macartney, op. cit., n. 16., at p. 250. Rhodes, op. cit., n. 17, at p. 199 has an account of the incident.

114 There is a copy in PCOM 9/98 of the Instructions as to Arms and Ammunition in Convict Prisons. Dartmoor Prison. 
a military prison. ${ }^{115}$ The hope in the Home Office about this time was that Dartmoor would not again be used as a convict prison; the lease of the land from the Duchy of Cornwall was due to expire in 1949, providing a convenient moment for abandoning the place. ${ }^{116}$ In 1945 a Borstal Institution was established there, but this did not prove a success and it closed in January 1946 . The prison population rose considerably after the war, and by 1947 was running at about 16,000 , as compared to about 11,000 in 1939 . So Dartmoor was brought back into use as a convict prison in 1947.

With the return of the convicts came the return of the armed guards for outside working parties. ${ }^{117}$ By 1947 the prevailing view amongst Home Office officials and the Prison Commissioners was that the armed guards were a bad idea. But the Governor, Major G.B. Harvey, to their irritation, reintroduced them without either consulting or informing the Home Office. The reason was a series of escapes from outside working parties. On 17 July Eric Williams and Knowles Bebbington made a run for in the mist; both were soon recaptured. Three more convicts made a run for it on August 11; two were rapidly recaptured but Henry Bailey, who was out for a couple of days longer, was even hunted by helicopter. On 14 August Cecil Davies, leapt over a wall and made off; the Times does not record his recapture, but I imagine he was soon back inside. ${ }^{118}$

By this time the stock of weapons had dwindled and consisted of a mere thirteen single-shot Snider Enfields, which possessed no safety catches and could not therefore safely be carried loaded; they were antiques, and could have been close to a century old. The armed guards carried cartridges in a pouch, to be loaded when required; presumably they were the type approved in 1898, loaded with AAA shot with the quantity approved in 1902.

An entertaining exchange of views was provoked by the discovery that the guards were back. It was generally agreed that the weapons were more or less completely useless for maiming fleeing felons. One official, not yet steeped in Home Office culture, brightly suggested their replacement by submachine guns, the Sten gun being the weapon of choice; he appreciated that there might be political problems if they were used. ${ }^{119}$ Harvey also made use of mounted patrols, but they were armed only with staves. Two different sets of instructions were available to the guards. One drew attention to the fact that only felons were shootable; the other did not. Guards who fired were to first fire high, then low. Under Governor Harvey's 1947 regime, not all

115 See HO 45/25078. See, also, PCOM 9/402, dealing with a disturbance involving 200 convicts who stood fast when ordered to go to work in 1941, and PCOM 9/403, dealing with assaults on prison officers in the 1940s.

116 There had been a 99-year lease in 1849 .

117 What follows is based on PCOM 4/405.

118 See the Times for 18 and 19 July and 12, 13, and 15 August 1947.

119 The Sten gun could be set to fire single rounds or to automatic operation. It was only effective as a military weapon at close ranges. It sometimes fired on its own initiative if dropped. 
parties were accompanied by armed guards; thus, parties of felons nearing release were exempted. But there were three working parties, each accompanied by three armed guards, who remained separate from the working party itself. After some vacillation, the officials concluded that, since armed guards had been reintroduced, it would appear to the felons as a sign of weakness to withdraw them. So they were allowed to remain. After much discussion it was agreed that so long as they were in parties not accompanied by armed guards misdemeanants could work outside. Armed guards for other parties were to be instructed only to shoot at members of their own parties.

I have not established precisely when the arming of the guards was discontinued. As we have seen, the practice was criticized in the Benson report of $1952 .^{120}$ It came up for consideration by the Advisory Committee on the Treatment of Offenders on 8 July 1952:

Mr. Benson asked whether it was necessary for the felon prisoners working outside to be under armed guard. It was this kind of thing which gave Dartmoor a reputation for toughness - a reputation that the prisoners were not necessarily anxious to dispel. That attitude could do more harm than good. ${ }^{121}$

The meeting was chaired by Sir Frank Newsam, the Permanent Under Secretary, who replied:

... that public opinion must be considered. The armed guards might not be necessary, but it might be impolitic to remove them. Reforms of that nature must be carried out gradually.

Newsam was noted for his skill in avoiding actions which might cause political trouble for his minister. And without, so far as I have been able to discover, any formal recorded decision, the use of armed guards was, soon after this, quietly abandoned, and the press, though always interested in Dartmoor, seems not to have picked this up. They had certainly gone by 1954. A letter by K.B. Paice of 14 September 1954 states that the practice of arming guards had continued until 'very recently'. ${ }^{122}$ In a book by Lionel Fox, chairman of the Prison Commissioners, published in 1952, it is said that:

The English prison officers carry staves (concealed in a special pocket) for use only when essential and in self-defence, but no firearms or tear gas or the like are held in prisons.

This he said marked a difference between English and American prisons. ${ }^{123}$ Somebody must have pointed out, perhaps at the proof stage, that this

120 HO 326/66 (Benson Report).

121 PCOM 9/1320. Also HO 326/57.

122 PCOM 9/1689 deals with an enquiry from the New Zealand Department of Justice.

123 There is a voluminous literature on the use of deadly force against felons in United States law; the leading case is Tennessee v. Cleamtee Garner, et al, Memphis Police Department v. Cleamtee Garner et al (1985) 471 U.S.1, 105 S.Ct. 1694, which, by a majority, ruled that the use of deadly force to prevent the escape of felony suspects, whatever the circumstances, is unlawful and applies a test of reasonableness. 
statement was not accurate, so a footnote adds: 'Except at Dartmoor, where armed patrols cover the large parties working outside the wall." ${ }^{124}$ Major Harvey was still there as Governor when the guards had gone.

And from time to time in the 1950s, prisoners continued to make their bid for freedom, most entertainingly Cyril Bond, who, with connivance from two prison officers, simply called a taxi and left in it in November 1955, but was soon recaptured. ${ }^{125}$ In none of the incidents I have traced in the $1950 \mathrm{~s}$ is there any mention of shooting, and in the case of Harper Woodward, who made a run for it in heavy rain and mist in November 1954, the press noted that he had been chased, with no mention of shooting. ${ }^{126}$ Typically he was soon recaptured, wet and wholly exhausted. ${ }^{127}$ The most celebrated escape was that of the mad axeman, Frank Mitchell, in December $1966 .^{128} \mathrm{He}$ is thought to have been murdered at the instigation of the Kray brothers, and stories are told that his cadaver is in one of the pillars of the Hammersmith flyover, but it has never been found, and nobody has been convicted of his murder. But his escape, although it caused much alarm, did not lead to the reintroduction of the armed guards.

So it was that the practice of shooting at felons simply to prevent escape passed out of use, somewhere over fifty years after the last felon had actually been killed. The law on the subject remained constant until 1967, when the distinction between felonies and misdemeanors was abolished by the Criminal Law Act. So today there are no felons left to shoot. Felons have joined the club which contains the passenger pigeon, the great auk, and the dodo. But the ghost of the old doctrine lives on in the European Convention on Human Rights, in Article 2(b), in an odd provision included at the insistence of the British negotiators, reluctant to sign up to a Convention at odds with existing law. ${ }^{129}$ Across the Atlantic, in the United States of America, which inherited the same legal doctrines, there remain large numbers of felons, an uncertain number of whom are shot each year, and nobody there seems to care very much; I have been unable to find any statistics. $^{130}$

124 L. Fox, The English Prison and Borstal System (1952), see ch. 10 on security.

125 See the Times, 16, 21, and 25 November 1955.

126 See the Times 9 and 10 November 1954.

127 Compare Arthur Savory, 17 January 1955 who gave himself up, and Peter Evan, who only managed two miles from the prison before he was taken into a farm, drenched and frozen, and given hot tea; see Western Independent, 18 July 1954.

128 See MEPO 2/10805 and 10806.

129 It provides that the right to life will not be violated when death occurs as the result of the use of force which is no more than is absolutely necessary to prevent an escape from lawful custody.

130 United States law and practice are discussed by J. Walker, 'Police and Correctional Use of Force: Legal and Policy Standards and Implications' (1996) 42 Crime and Delinquency 144-53, noting ten fatal incidents in 1994. 
For those who like stories to be related to legal theory, this one is all about the relationship between law, practice, official culture, and evolving perceptions of morality. Some will like this to be spelled out, but my own preference is for readers to be allowed to work all this out for themselves. 